\title{
Political Economy and the Routinization of Religious Movements: $A$ View from the Eastern Woodlands
}

\author{
Robin A. Beck Jr. \\ University of Michigan \\ and \\ James A. Brown \\ Northwestern University
}

\begin{abstract}
Max Weber's concept of routinization offers a useful framework for understanding the relationship between political economy and the organization of religious movements. Here, we apply this concept to a comparison of Hopewell and Mississippian, two of the most important religious movements in the precolonial Eastern Woodlands. We focus on two archaeological contexts in particular-Mound 25 at the Hopewell site and Mound C at Etowahto illustrate how Weber's concept allows for a more nuanced comparison than concepts associated with a more traditional neoevolutionary logic. [political economy, routinization, Mississippian, Hopewell]
\end{abstract}

$\mathrm{H}$ opewell and Mississippian were two of the major cultural horizons of the precolonial Eastern Woodlands, each incorporating nearly half a continent. Each was distinguished by monumental earthwork constructions and spectacular mortuary practices; by cosmologically potent sacra and regalia expertly crafted from exotic raw materials such as marine shell, copper, and mica; and by large-scale networks of interaction and exchange. Attention to these monuments and preciosities drove the agenda for much of the first century of American archaeology, such that Hopewell and Mississippian have been subjects of archaeological inquiry for more than 200 years.

For the past half century, Mississippian society has usually received more attention from anthropological archaeologists than Hopewell. In part, this is because a range of ethnohistorical documents by Spanish and French explorers offer direct observations of some late Mississippian societies and their immediate descendants. Moreover, many Missis- sippian peoples lived in large towns and villages, such that the footprints of their everyday lives are more accessible to modern archaeologists. Hopewell people, on the other hand, spent much of their daily lives in dispersed homesteads and hamlets that have left but a relatively ephemeral material signature. Finally, the concept of the chiefdom, often uncritically linked with neoevolutionary models, has proved to be quite resilient (if also limiting) in developing an anthropological understanding of leadership and polity in Mississippian society. It is with Hopewell society, however, that the potential pitfalls of neoevolutionary logic become apparent. There is little evidence of Hopewell centralization since clear-cut polities are difficult to discern, and the Hopewell phenomenon is recognized as a broad entity first and foremost by its mortuary signature. Yet the craft specialization that is evinced by some of its ritual objects does indicate some form of complexity. Hopewell societies - according to the strict neoevolutionary logic - should therefore be 
understood as complex tribes or as simple incipient chiefdoms, evolutionary precursors of their Mississippian counterparts.

We are certainly not the first to suggest that neither of these options is acceptable, at least without selectively reworking the square Hopewell peg to make it fit the round, neoevolutionary hole. Here, we approach the problem of comparing Hopewell and Mississippian from a different perspective, one that departs from the usual point of view of political leadership. We will instead treat these entities as religious movements, and we will aim to articulate their differences through the organization of ritual life, specifically drawing upon Max Weber's routinization concept. Let us emphasize at the outset: we do not assume that Hopewell and Mississippian were homogenous phenomena. Ohio Hopewell culture differed from Hopewell manifestations in the Lower Illinois Valley, in southern Indiana, and across the Appalachian Summit. Likewise, Mississippian polities such as Cahokia, Moundville, and Etowah were more than geographically distinct reiterations of the same religious blueprint.

This said, the goal of this chapter is to compare the broader cultural patterns of Hopewell and Mississippian, but to do so in a chapter-length undertaking we need to limit our discussion to a more manageable scope. We have therefore selected two particularly iconic cases through which to compare these religious movements: Mound 25 at the Hopewell site in Ohio and Mound $\mathrm{C}$ at the Etowah site in Georgia. Similar kinds of ritual practices were enacted at each of these places: earth moving, funerary rites, and the deposition of special objects, many of which were crafted of the same materials and even shared thematic content. But key distinctions in how these practices were locally organized, as viewed through the lens of routinization, illustrate the broader cultural distinctions between Hopewell and Mississippian ritual. Before turning to these particular cases, we need to outline the concept of routinization and suggest an analytical framework for linking it to different forms of political economy.

\section{Routinization and Political Economy}

Following Max Weber, we may refer to religion and cult as "the relationships of humans to supernatural powers which take the forms of prayer, sacrifice, and worship" (Weber 1993:28). Novel religious or charismatic movements often achieve traction during moments of social crisis, when existing ideals and ideologies fail to make sense of the world as it is experienced. William Sewell (2005) refers to such moments as structural disjunctions. Social struc- tures, as defined in his model of social change, consist of virtual rules (schemas) and actual material resources, each of which ideally validates and recursively sustains the other. During episodes of crisis, however, resources and schemas that mutually constitute structures are temporarily disjoined. Disjunction cannot be socially tolerated for long stretches of time, such that a creative solution to the crisis - a method for restoring resources to schemas - can secure broad acceptance rather quickly, even had it seemed an unthinkable outcome just prior to the rupture. Sewell (2005:248-257) suggests that these episodes of cultural dislocation and creative rearticulation, which he refers to as events, are marked by a heightening of emotion and an improvisation of ritual. Heightened emotions add to the instability of events and explain in part why they usually unfold in unpredictable ways. Such heightened emotional states may also compel people to embrace radically novel ideas during the rearticulation of resources and schemas; new ritual practices, in turn, may be invoked to sanction and formalize the new order during its coalescence (Beck et al. 2007:835).

In some cases, a charismatic leader may step into this disjunction to provide a charter for revitalizing the existing ideology or to propose a new movement altogether. For any charismatic authority to effect a durable transformation, however, the movement must undergo a process that Max Weber (1947:364) refers to as routinization, the process by which a charismatic authority is institutionalized. Weber argues that the motive for routinization is to create a stable social order, ideally and materially, in which the disciples of an original charismatic leader and their followers can ensure "the continuation and continual reactivation of the community" (Weber 1947:364). We may suggest, then, that a charismatic movement effects this transformation and is routinized or fails to do so and is quickly exhausted.

Weber insists that charismatic authority - in its original state - is outside the provenance of "everyday routine and the profane sphere" (Weber 1947:361). Such authority represents a revolutionary repudiation of and break with rational and traditional forms of authority, which are legitimized in rules, routines, and precedents; it is thus that a charismatic authority achieves traction in times of crisis, when the traditional forms of authority fail to make sense of practical everyday experience (i.e., when the existing schemas cannot accommodate their respective structural resources). Such charismatic authority tends to be ephemeral, however, since the only basis of its legitimacy is the personal charisma of its leader, which itself may last "only as long as the belief in its charismatic inspiration remains" (Weber 1947:362). Routinization thus involves a transformation in the character of the movement, from the initial basis in charisma to a subsequent grounding in rules, routines, and precedents 
(i.e., to a rearticulation of structural resources and schemas). Moreover:

For charisma to be transformed into a permanent routine structure, it is necessary that its anti-economic character should be altered. It must be adapted to some form of fiscal organization to provide for the needs of the group and hence to the economic conditions necessary for raising taxes and contributions. [Weber 1947:369]

A routinized movement requires the creation of novel symbols, rituals, and paraphernalia, as well as support for its practitioners. Weber refers to these practitioners as "priests," a role that he contrasts with those of "prophets" and "magicians" (Weber 1993:47). We may perhaps read the term shaman for magician, and Augusto Oyuela-Caycedo has defined routinization as "the critical threshold practice of the change from shamanism to priesthood" (Oyuela-Caycedo 2001:6). We want to be careful in using the term priest, however, since it can also imply a kind of functionary or an occupational specialization that formally separates one class of people from their neighbors in everyday life as well as in matters of religion, ritual, and cult. It is preferable, then, to treat Weber's "priests" in a more general sense, as Talcott Parsons suggests:

Weber's distinction is that the magician's function copes with relatively ad hoc interests and tensions, while the priestly function is organized into a systematic and stabilized cult, which is to a significant extent independent of the ad hoc exigencies which impinge upon the ordinary population of the society. [Parsons 1993:xl]

Oyuela-Caycedo is also careful to point out that the rise of such a cult (i.e., the routinization of a charismatic movement) need not imply the end of shamanic practices. Rather, "shamanism [i.e., Weber's magic] will always be present as an alternative form to the establishment and may even coexist in the religious sphere" (Oyuela-Caycedo 2001:6).

Weber also offers that priesthoods should be manifested "by the presence of certain fixed cultic centers associated with some actual cultic apparatus" (Weber 1993:28-29). Such centers are often conceived by their builders and users as imago mundis, as images or replicas of the cosmos, or as axis mundis, the cosmic center (e.g., Eliade 1959; but see Jones' [2000:37-39] caution against the uncritical application of these general homologies to any specific case). In fact, Oyuela-Caycedo (2001:6) views the construction of a cultic center as the key attribute of routinization. The center thus becomes a durable place situated within the cultural landscape where cultic practitioners and their observers enact routinized rituals and manipulate associated paraphernalia.

Harvey Whitehouse (2004) explores routinization in his theory of modes of religiosity, in which he contrasts "doctri-

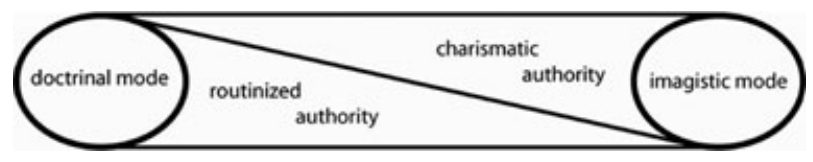

Figure 6.1. Modes of religiosity.

nal" and "imagistic" religious modes. The ritual actions that constitute his doctrinal mode are highly routinized and characterized by frequent repetition; while these are effective qualities for memorization, they may also result in rote performance and lower levels of personal motivation - what he calls the "tedium effect" (Whitehouse 2004:66). Those practices that constitute the imagistic mode are not routinized and are only enacted infrequently, making them difficult to bring under institutional controls; at the same time, however, they are characterized by very high levels of emotional arousal (Whitehouse 2004:70). The doctrinal and imagistic modes are, like the categories proposed by Weber, ideal types, and Whitehouse recognizes that in actual practice any particular cult or religious performance may combine qualities of both modes. Thus, while the Whitehouse model might appear to favor a more restrictive use of the routinization concept than Weber's, we believe that these perspectives are reconciled quite easily, as indicated in Figure 6.1.

As Weber notes, the routinization of any religious movement is tied to an economic basis or fiscal organization, and this requires surplus generated through political economy. Any group that elects to support the movement-e.g., families, kin groups, sodalities - must contribute to the process of its financing. All of the different practices and actions that constitute the religious or ritual circuit-constructing a center; feasting; acquiring exotics; crafting preciosities, costumes, regalia, and paraphernalia - require contributions from the participants, and this can ultimately be conceived as physical labor. We suggest that different modes of social organization may emerge through routinization, depending upon the kind of political economy that finances the process. A political economy based upon surplus production, especially on production of one or more staple cereal crops, supports quite different social processes than those economies based upon ad hoc or opportunistic surplus procurement. Let us briefly elaborate these conditions.

If a political economy is based upon the production of a staple cereal crop, then surpluses are generally dependable and predictable (barring agricultural catastrophes like droughts, blights, flooding, etc.). This means that wellsituated constituencies, particularly those with access to the best agricultural land, can consistently and predictably outproduce their less fortunate neighbors from one year to the next. As this production is what finances the routinization 
process, affluent constituencies enjoy a greater capacity to determine the nature and direction of the movement, or to wield what Eric Wolf has referred to as structural powerthe power to set the agenda:

By this I mean the power manifest in relationships that not only operates within settings and domains but also organizes and orchestrates the settings themselves, and that specifies the direction and distribution of energy flows. In Marxian terms, this refers to the power to deploy and allocate social labor. [Wolf 1999:5]

Where rules of reciprocity are in effect, less productive constituencies might exchange their labor for rights to participate in the ritual circuit. If disparities in structural power and affluence can be sustained across generations, then routinization may sanction hereditary inequalities.

If a political economy is based upon hunting, gathering, and small-scale cultivation, then the process of routinization is financed by an opportunistic or ad hoc surplus procurement. This mode of political economy is unpredictable, in that while surpluses may be consistently available to ensure the movement's long-term viability, it is difficult to predict which constituencies can or will procure more surplus annually. In part, this is because the sources of most wild food surplus are usually more dispersed-and thus more difficult to control - than the sources of an agricultural surplus. Power and affluence are less heritable under such conditions, and economic imbalances relative to the financing of the ritual circuit tend to be temporary and situational. Here, structural power is maintained by clans, sodalities, and other constituencies that cross-cut genealogical ties and that emphasize personal prestige and achievement. Having briefly detailed this link between routinization and political economy, we can turn to our study of Hopewell and Mississippian and to the specific cases of the Hopewell and Etowah sites.

\section{Mortuary Ritual at Hopewell Mound 25 and Etowah Mound C}

The routinization concept should be especially appealing to archaeologists, as its basis in the political economy explicitly binds it to material experience; that is, we should see evidence of routinization processes manifested in the material of the archaeological record. The construction of new cultic centers, changes in ritual practice - especially in mortuary ritual - and the crafting of new styles of regalia and other accoutrements are all amenable to archaeological analysis. When we identify formal and patterned changes across such domains, we may infer the routinization of a religious movement. Oyuela-Caycedo argues persuasively that archaeologists already have a terminology for this process in concepts like culture area and culture period. He observes that the artifact distributions indicated by these terms represent "the temporal and spatial reach of religious cults" (Oyuela-Caycedo 2001:6). In place of these terms he offers religious complex, meaning

the system of shared cosmological views that are expressed in low statistical variation in the religious material artifacts and religious architecture. This religious complex usually operates above the level of political units, languages, and economic units.... [and] can expand and contract in space, depending on the rise of new crises and the success of the process of routinization in the landscape. [Oyuela-Caycedo 2001:6]

While this concept has much to recommend it, we must include a caveat as regards our particular study: neither Hopewell nor Mississippian was ever a homogenous religious complex. Rather, as we have already stated, these concepts subsume a range of historically interrelated but culturally and linguistically diverse cases. It is these cases, we suggest, that represent the relevant religious complexes. However, in selecting for our comparison the particular cases of Hopewell's Mound 25 and Etowah's Mound C, we do assume that each can broadly represent its respective religious movement; that is, we assume that the different religious complexes that constitute Hopewell and Mississippian share broadly patterned similarities.

In describing Hopewell and Mississippian as religious movements, we acknowledge that there are many distinct ways of theoretically situating these phenomena. Hopewell, for example, has also been identified as a long-distance exchange network (Struever 1964), an artistic style (Prufer 1968), an interaction sphere (Caldwell 1964), a peer polity network (Braun 1986), a kind of mortuary cult (Prufer 1964), and a religion (Caldwell 1964; see also Carr 2005b:576-577 for a broader discussion of the history of these perspectives). Mississippian too has been defined by qualities other than its ideational or religious aspects, including its material culture attributes (see Griffin 1985 for a summary), its reliance on agriculture (Griffin 1967), and its cultural adaptation to a particular habitat (Smith 1978) or set of organizational challenges (Muller 1997). Again, the aim of this brief summary is not to impress an overly simplistic homogeneity on either Hopewell or Mississippian but to establish a context for comparing broad cultural patterns.

\section{Hopewell}

The Hopewell era dates from about C.E. 100 to C.E. 300 and witnessed its greatest elaboration in the 
Midcontinent, particularly in the Ohio River Valley. It is here at centers such as Mound City, Marietta, and Newark that Hopewell culture entered into the national consciousness, fueling mid-nineteenth-century debates about the so-called moundbuilders (Meltzer 1998; Silverberg 1968). We now know that Ohio Hopewell earthworks did not have permanent aggregations of villagers. Instead, these locales were centers of periodic ceremony and ritual, including mortuary practices, mound building, feasts, exchange, and broad social interactions (see Carr and Case, eds. 2005; Charles and Buikstra 2006; Dancey and Pacheco 1997; and Pacheco 1996 for up-to-date edited works on the Hopewell phenomenon). Most Hopewell people occupied dispersed homesteads and hamlets and practiced a mixed subsistence based on hunting and fishing, gathering, and the cultivation of starchy seed crops like chenopod, sumpweed, maygrass, and sunflower.

As noted, the Hopewell phenomenon was not limited to the Ohio Valley but spread as far south as Florida in the east and Louisiana in the west. Hopewell thus provides a blanket term for the shared ceremonialism that linked diverse Middle Woodland peoples in much of eastern North America. The term Ohio Hopewell refers to the specific religious complex where most of these rites, crafts, and practices had their greatest elaboration. Hopewell-affiliated religious complexes include the Havana mortuary tradition in Illinois (Brown 1981; Buikstra 1976; Carr 2005a; Deuel 1952; Struever 1965; Tainter 1977), the Marksville phase of the Lower Mississippi Valley (Ford and Willey 1940; Kidder 2002; Toth 1979, 1988), the Copena mortuary complex in Alabama and Georgia (Beck 1995; Knight 1990; Walthall 1973, 1979), and the Mann phase in Indiana (Adams 1949; Carr 2005a; Ruby 1993, 1997).

Across much of the midcontinental and southeastern United States, the dramatic opening of the Middle Woodland period represents an elaborate rearticulation of the social structures and practices gradually disjoined during the Early Woodland, when people first made widespread use of pottery vessels and began to cultivate significant quantities of indigenous seed crops. Some of these plants were domesticated as early as the Late Archaic period (e.g., Fritz 1990; Smith 1989), but it was only in the Early Woodland (after 1000 B.C.E.) that their contribution to prehistoric diets became substantial. The cultivation of such crops was much more important in the Midcontinent than in the lower South, where local environments had shorter periods of winter (e.g., Fritz 1990; Gremillion 2002). While maize was introduced during the Middle Woodland, only a few kernels are known from a handful of sites, and while Smith (1989) suggests that starchy seed production could have substituted, these crops did not have the $\mathrm{C} 4$ carbon pathway that

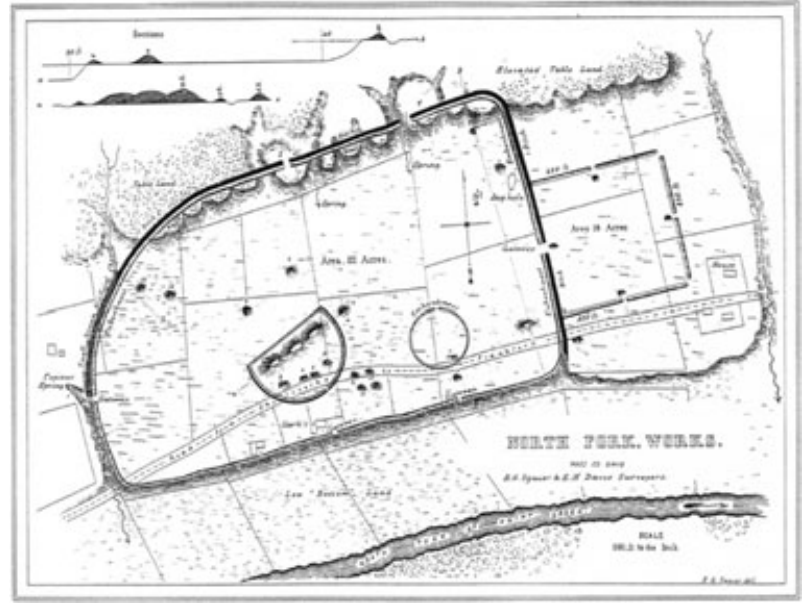

Figure 6.2. Plan view of the Hopewell Mound site (Squier and Davis 1848:27).

permits cereals to be significantly more productive. Hence cereal grain production could not have been a factor in the Hopewell phenomenon. The effect of fishing is also quite clear. Middle Woodland sites abound in the Mississippi watershed, where backwaters and oxbow lakes prevailed and where there was an annual renewal of fish stocks - these are the Middle Woodland sites that document the longest continuity of occupation. It is thus important to recognize that Middle Woodland ceremonialism reached its zenith in locales like the Scioto Valley of south-central Ohio, where fishing potentials (and thus surplus potentials) were only modest. We may now turn to an exemplary case from the Ohio Valley: the eponymous Hopewell site, and specifically its Mound 25.

The Hopewell site (33Ro27) is located in the heart of the Ohio Hopewell country, the Central Scioto region of Ross County. Hopewell is an immense site with more than three kilometers of earth and stone walls that delimit two adjacent enclosures (Figure 6.2), the largest of which, often referred to as the Great Enclosure, covers more than 40 hectares and conforms over much of its area to natural topography; the second, smaller enclosure - joined to the eastern wall of the Great Enclosure - is a square that measures about seven hectares. Within the walls of these enclosures, no fewer than 40 mounds have been recorded, some of which are as small as three meters in diameter and 30 centimeters high (Greber and Ruhl 2000:11-12). The Hopewell site was recorded by Caleb Atwater in 1820, but E. G. Squier and Edwin Davis (1848) conducted the first significant excavations there in 1845. Since then, two major excavations have taken place within the enclosures: Warren Moorehead's work from 1891 to 1892 (Moorehead 1922) and that of Henry Shetrone of the Ohio Historical Society from 1922 to 1925 (Shetrone 1926). 
Most of the Hopewell site is currently part of the Hopewell Culture National Historical Park.

Towering above the site, and enclosed within its own semicircular earthwork and moat, is Mound 25, the largest mound ever constructed by Hopewell peoples. Now an elongated, oblong-shaped earthwork, Mound 25 once contained three recognizable parts that together measured 150 meters in length; its eastern part rose about nine meters at its highest point (Greber and Ruhl 2000:31). Given the era when Moorehead and Shetrone worked, their field notes tend to be less detailed than what today's archaeologists expect. Greber and Ruhl (2000:30-51), however, have recently used these notes to offer a plausible reconstruction of Mound 25 's stratigraphy. The East and West mounds were relatively simple constructions, particularly in comparison with the complex stratigraphy of the Central Mound. Moreover, both the East and West mounds covered bare prepared floors that contained very few features, suggesting that people may have used these floors as plazas (Greber and Ruhl 2000:33). It is in the Central Mound, with its structures, burials, altars, and remarkable artifact deposits that we will find our best insights into Hopewell religious practice.

The floor surface under the Central Mound was made of layers of puddled clay deposited over clayey subsoils stripped of their vegetation and topsoil, forming a very compact surface that has been referred to as "Hopewell concrete" (Greber and Ruhl 2000:34). At least two substantial wooden structures - likely charnel houses - were built on this floor: the largest, oval structure was $60 \times 40$ meters, was located under the north-central part of the mound, and was apparently subdivided into western and eastern units; the other large structure was circular, about 25 meters in diameter, and was located beneath the northeast part of the mound. The oval structure contained two prepared clay basins or altars, one each in the western and eastern units, while the circular structure held a single altar (Greber and Ruhl 2000:42; Moorehead 1922:113-114). A smaller structure, less than 10 meters in diameter, was southeast of the larger structures and enclosed a single burial. When use of the large structures ended, they were dismantled and partially burned. Sterile clays were piled on top of the still-smoldering debris, and when this clay cap reached a depth of about one to two meters, a cache of cut copper artifacts was deposited over the western unit of the largest structure, now entombed by this early mound stage.

All three of the structures contained burials, though of the 102 individuals recorded under Mound 25, more than 80 percent were associated with three groups located in the two largest structures (Greber and Ruhl 2000:42). Greber and Ruhl's Group C was located in the circular, northeastern structure and contained 35 individuals; Group D, located in the eastern unit (or room) of the oval structure, contained 17 individuals; and Group E, placed in the western unit of the structure, contained 30 individuals (Greber and Ruhl 2000:table 2.1). Each burial group contained cremated secondary and extended primary remains, and the most frequent cover was a log tomb with a bark or timber roof. Greber and Ruhl suggest that these groups represent three distinct constituencies within the broader society that used the Hopewell site (Greber and Ruhl 2000:45). While the majority of individual inhumations did not contain artifacts, a wide variety of items was deposited in burials, including pearls, beads, copper objects such as ear spools and plaques, marine shell and the teeth of aquatic animal species, bone and flint tools, large canines, and cut mica. Greber and Ruhl's statistical analyses of artifact associations indicate that the distribution of artifact classes is quite similar across groups, suggesting little evidence for intergroup social ranking (Greber and Ruhl 2000:45).

One of the things that draws us to Mound 25, of course - and that makes this context such a compelling contrast with a place like Etowah's Mound C-is its assemblage of carefully crafted objects, and particularly the distribution of these objects throughout the mound and its submound features. As noted, many special objects were found in association with human remains, but it is perhaps more telling that most of the exotic and finely crafted items from Mound 25 were placed apart from such interments, with the greatest number deposited in "altars" 1 and 2, located in the western and eastern units of the large oval structure, respectively (Greber and Ruhl 2000:61). In his description of excavations at another Hopewell site, Mound City, William Mills (1922) preferred the term crematory basin to that of altar, employed both by Squier and Davis (1848) and by Warren Moorehead (1922) at Hopewell. The style of these features was similar at both sites, but most of those that Mills opened at Mound City contained no artifacts, unlike the exceedingly rich examples from Hopewell. Greber and Ruhl observe that both terms are probably reasonable for their respective cases, but they prefer the neutral term clay basin (Greber and Ruhl 2000:59). We appreciate their caution, but for simplicity's sake will refer to them as altars 1 and 2 .

Altars 1 and 2 were large features - though the size of al$\operatorname{tar} 1$ was apparently not recorded, Charles Willoughby, who studied the Hopewell site collections from 1892 to 1894, did record that altar 2 measured 7 feet (2.13 meters) in length by 5.75 feet ( 1.75 meters) in width. The altar's basin or depression measured 15 inches ( 0.38 meters) deep, 3.3 feet (1.0 meters) long, and 2.5 feet ( 0.76 meters) wide (Greber and Ruhl 2000:61). Each altar was filled with hundreds of exotic objects, many of which, as Willoughby noted in his analysis, "were cracked, broken, or utterly destroyed by the 


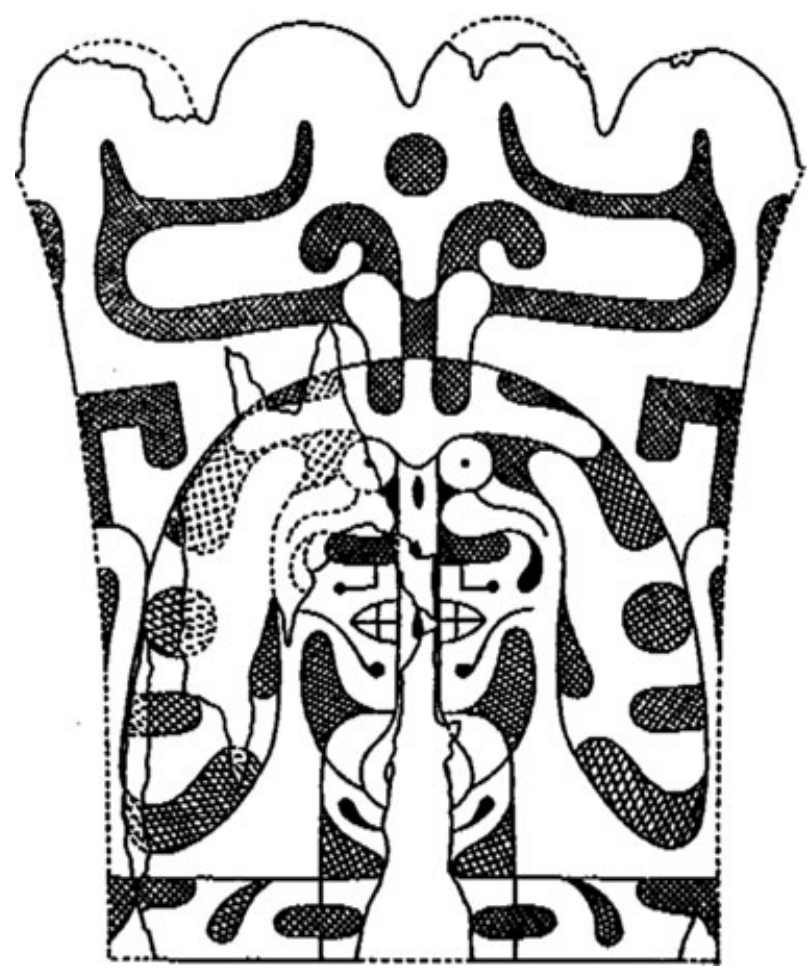

Figure 6.3. Engraved human femur from the Hopewell site (after Greber and Ruhl 2000:198).

intense heat" of the last fires kindled in the basins (Greber and Ruhl 2000:60). In fact, animal fat or pitch was used as a fuel or accelerant for the flames, turning many of the objects, according to Willoughby, "a deep, lustrous black throughout" (Greber and Ruhl 2000:60). These preciosities were thus permanently removed from circulation right before the charnel house was intentionally dismantled, burned, and buried under the earliest mound stage.

There are significant distinctions in the kinds of objects and materials recovered from the two basins. Altar 1 held over 500 copper ear spools, a few of which were covered with silver or meteoric iron, and "many finely executed carvings of wood, bone, antler, ivory, shell, and stone" (Willoughby in Greber and Ruhl 2000:60). The carvings are particularly enigmatic, representing avians, felines, and bear claws, and one example, carved on a human femur (Figure 6.3), is a composite figure that combines human, deer, and avian features. Altar 2, however, held over 100 blades of obsidian and hundreds of broken pieces, all of which have been traced to the Yellowstone-based Obsidian Cliff quarries located 2,400 kilometers west of the Ohio Valley (DeBoer 2004:94; Griffin et al. 1969). Both altars additionally contained large quantities of other materials, including perforated bear claws and teeth; pearls (more than 19,000 in altar 1); quartz crystals; a variety of small items made of copper, silver, meteoric iron, and mica; beads of bone and shell (nearly 3,000 bone beads from altar 2 were crafted from the wing bones of small birds); platform pipes (five were found in altar 2); and the cut mandibles of quadrupeds.

Two other important deposits merit note here. About three meters from altar 1, skeletons 260 and 261 were covered by a large artifact deposit measuring 2.1 meters long by 1.5 meters wide. Included were thousands of pearl and shell beads and hundreds of copper objects including plates, axes, adzes, a headdress in the shape of deer antlers, and bird effigies; at least two intricately carved bones, one on a bird humerus and the other on a human femur, were also included in the deposit (Greber and Ruhl 2000:72-75). About three meters from skeletons 260 and 261 was a large, extraordinary assortment of symbols and ornaments made of thin copper sheets and carefully packaged between two layers of bark. While many of these are two-dimensional cut-outs of abstract designs, others are readily identifiable as bear teeth and claws, fish, and deer antlers. We will return to these artifacts and to the method of their deposition in the final section of this chapter, when we compare Mound 25 to Mound $\mathrm{C}$ at Etowah. For now, we shift our attention to the case of the Etowah site and to the broader social context of the Mississippian movement.

\section{Mississippian}

The Mississippian era dates from about C.E. 1000 to C.E. 1500 and is best known for the mound complexes at sites like Cahokia, Moundville, Etowah, Lake George, Kincaid, and Spiro. Unlike Hopewellian earthworks, Mississippian centers were usually aggregated towns housing large and permanent populations. Cahokia, situated on the Mississippi River in southwestern Illinois, was the largest town in native North America, spreading over several square kilometers and housing as many as 10,000 people (e.g., Emerson 1997; Milner 1998; Pauketat 1994, 2004; Pauketat and Emerson 1997). Moundville, on the Black Warrior River in Alabama, covered about 75 hectares and early in its history may have had a population of 1,500 (Knight and Steponaitis 1998). Most Mississippians practiced maize agriculture (along with beans and squash) and supplemented their production of this cereal crop with fishing and hunting and gathering of wild food resources. While Hopewell mounds and earthworks exhibit geometric banks and enclosures, large Mississippian towns often exhibit a pattern in which one or more flat-topped, pyramidal mounds flank a central plaza, as is clearly shown in the plan of the Etowah site (Figure 6.4). Mississippian, as with Hopewell before it, can be viewed as a term for the shared religious practices that drew together 


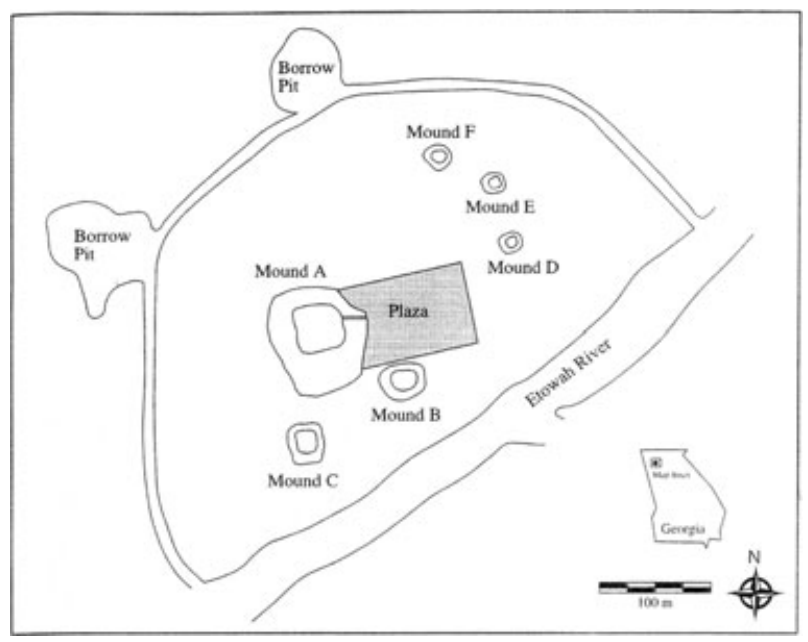

Figure 6.4. Plan view of the Etowah site (after King 2003:51).

a diverse range of peoples and language families across the late precolonial Eastern Woodlands.

Across the lower Midwest, in places like the American Bottom, people began to intensify the production of maizea cereal crop native to northern Mesoamerica and introduced by way of the American Southwest - in terminal Late Woodland times (about C.E. 800-900). This growing dependence on maize, itself the product of specific Late Woodland needs and strategies (detailed treatment of which is beyond the aims of this chapter, but see Emerson et al. 2000), transformed Late Woodland land tenure and settlement practices, offering farmers both a storable surplus and a dependable (i.e., predictable) dietary staple. As this political economy expanded, communities were faced with a radically different set of challenges and opportunities than those faced by their immediate forebears, promoting an erosion of traditional institutions and an amplification of new political, religious, and economic practices (Beck et al. 2007; Brown 2006; Kelly 1990a, 1990b; Pauketat 1994, 2004; Welch 1990). It is within this context that people in the American Bottom, shortly after C.E. 1000 and probably at the burgeoning town of Cahokia, drew together a diverse range of such practices into the religious movement that we refer to as Mississippian. This is not to suggest in a simplistic way that maize caused the spread of Mississippian, but rather to suggest that this Mississippianization of the Southeast and lower Midwest - a process - was an unintended consequence of another process, maize intensification. We turn now to one Mississippian center, the Etowah site, and specifically to its mortuary facility, Mound C.

The Etowah site is a large multimound town that rose to prominence along the eponymous river's broad floodplain in northwest Georgia. Etowah has six known mounds, the largest of which, Mound A, rises to a height of 21 meters. The site is surrounded on three sides by a deep moat that encloses 21 hectares and is protected on its east by the Etowah River (King 2003:50-51). Etowah has long been counted among the preeminent archaeological sites in the southeastern United States. Rev. Elias Cornelius offered the first published description of the site in 1818, and it was depicted for the first time by Charles C. Jones Jr. in 1861. Etowah's true renown, however, rests on the excavations conducted within its famous burial mound, designated Mound C. John P. Rogan, working under the auspices of the Smithsonian Institution's Bureau of Ethnology, first explored Mound C in 1883, work that yielded a set of copper plates - now known as the Rogan plates (Figure 6.5) - that are among the most ubiquitous examples of Mississippian art (Thomas 1894:292-312). Warren Moorehead (1932) conducted extensive excavations at Etowah from 1925 to 1927, and while his Mound C diggings yielded a rich array of Mississippian mortuary art, his work itself was generally sloppy and poorly recorded, much like his work at Hopewell. It was long assumed that Moorehead's project had entirely depleted the mound, but Lewis Larson's complete excavation of the Mound C remnant from 1954 to 1962 surprisingly yielded a tremendous wealth of new mortuary data; more important, his careful program of mapping and data recovery made it possible to understand Mound C's construction history (Larson 2004).

Construction on Mound $\mathrm{C}$ began during the period from C.E. 1250 to C.E. 1325 , and the mound eventually reached a height of six meters. Mound $\mathrm{C}$ was built in seven stages, each with burials placed in the mound's summit or around its base and flanks; in all, 366 burials were removed by Rogan, Moorehead, and Larson (King 2004:156-158). According to Adam King (2004:158), the earliest three stages were built between C.E. 1250 and C.E. 1325, and each was surrounded by a wooden palisade that screened the mound precinct from everyday life. The most common burial types during this time were either simple pits or stone-lined tombs, while the most elaborate interments - including those discovered by Rogan - were deposited in the mound summits, probably under the floor of a mortuary temple. Later, from C.E. 1325 to C.E. 1375, four new mound stages were added. Burial types continued to include simple pits, but log-lined tombs replaced the earlier stone-lined tombs. The practice of interring burials on the mound summits also changed, as rich burials were now placed on the mound's north flank and covered with earth, forming a lobe (King 2004:158).

Many archaeologists treat Etowah as an iconic example of a Mississippian chiefdom, and we would not suggest otherwise. But most of our models of social organization in Mississippian polities are based on the notion that social power was concentrated in the hands of one hereditary leader 


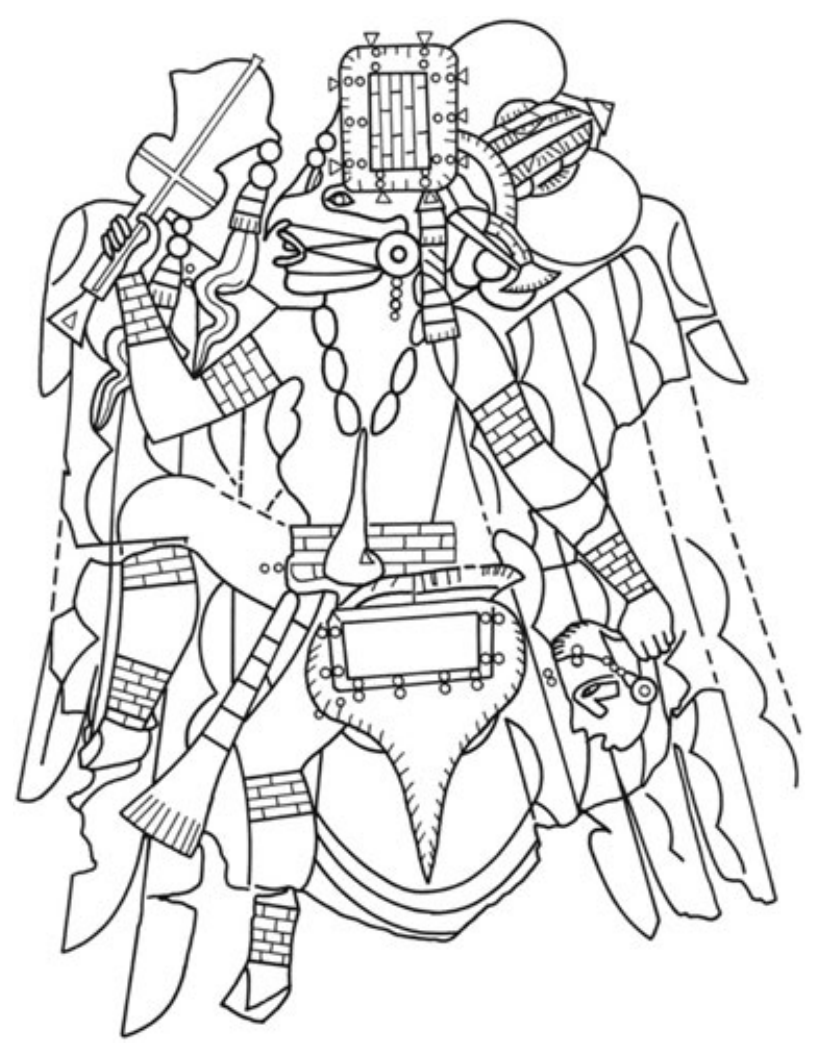

Figure 6.5. Copper "Birdman" plate from the Etowah site.

(the chief) or among only a few closely related individuals. This perspective can be traced to Service's (1971:148-157) insistence that a structure similar to that of the ramage, a Polynesian unilineal descent group in which members are ranked relative to their genealogical distance from an apical ancestor, is a universal feature of the chiefdom type. Vernon J. Knight Jr. (1990) has used ethnographic data from across the late postcontact era Southeast to offer a powerful critique of Service's model, as regards southeastern chiefdoms, and Adam King's recent analyses of artifact distributions within Mound $\mathrm{C}$ now provide striking archaeological support for this critique. King (2004:160-163) has discovered that both the spatial arrangement of burials and the distribution of certain types of shell gorgets suggest that elite status at Etowah was not restricted to the members of a single family. Rather, prestige and authority during the height of Etowah's power appears to have been dispersed among different kin-based constituencies, each of which claimed rights to a distinct quadrant of the funerary mound. Brown (2007b) has recently identified these groups as social houses (maisons), using the concept coined by Claude Lévi-Strauss (1982).

Archaeologists have recovered a remarkable assortment of Middle Mississippian art from Mound C, including items such as embossed copper plates and regalia, marine shell gorgets, and polished stone statuary. Perhaps the best known of these objects are the "Birdman" copper plates that Rogan discovered in 1883 (Figure 6.5). Although this figure has long been interpreted as a realistic depiction of a victorious warrior in full "eagle dancer" regalia (e.g., Waring and Holder 1945), Brown (2007a; Brown and Dye 2007) has recently identified this being as none other than the mythical Osage Morning Star, a hero who triumphs over the underworld's forces of death during a cosmic game of chunkey and whose mastery ultimately reaffirms social continuity and the regeneration of human life. What is more, the source of these copper plates and their mythic associations was not the Etowah site and its environs, but rather the American Bottom - probably Cahokia itself. As King notes,

These data suggest that when Etowah reached its political peak, its leaders relied upon a foreign symbolic set that no doubt referenced a foreign mythology to justify their place in a ranked social order. That foreign style and mythology served to charter the power of Etowah's Middle Mississippian elites, and it was all the more compelling because of its association with what I suspect was largely a mythological place in the Mississippian world: Cahokia. [King 2004:160-163]

As evidence of the role that this mythical charter played in legitimizing the authority and prestige of Etowah's elites, several Mound C burials contained copper replicas of Birdman's (or Morning Star's) regalia, particularly headdress elements such as the bi-lobed arrow. In other burials, shell gorgets engraved in the local Hightower style contained images of Birdman in a variety of guises and postures. Etowah's elites, that is, were actively girding themselves in the garb of this foreign culture hero (King 2004:160).

Also worthy of special note are the matching stone statues discovered by Lewis Larson in 1954. The statues represent a man and a woman: the man sits cross-legged with his hands on his knees, and the woman sits in a kneeling position with her legs tucked beneath her and her arms at her sides. The former is 61 centimeters ( 24 inches) high, while the latter measures 56 centimeters ( 22 inches). The statues were crafted of local marble from western Georgia, and both were painted in red ochre and black carbon. No fewer than nine such statues are known to have been recovered at Etowah, as have many others from sites across the Mississippian world. Brown (1976, 2001, 2007b) and Knight (1986) have linked the statues with ancestor cults, specifically suggesting that these figures represent the founder or-as in the case of the matched male and female Etowah figures - the founding pair of a named corporate group such as a lineage or a social house. In this respect, the final deposition of the Etowah statues is quite revealing. Larson recovered the figures hastily dropped in a burial pit (Burial 15) at the base of Mound C. 
In fact, the male figure's right arm was broken off during its deposition (e.g., Stuart 2004:fig. 10). A jumble of human remains and funerary goods were also scattered across the floor of the pit. Above this feature, Larson found a scatter of human remains and other artifacts that continued up the ramp to the mound summit, likely the location of a mortuary temple. It appears, in sum, that an attack around C.E. 1375 destroyed the Mound $\mathrm{C}$ mortuary, an event for which there are clear ethnohistoric parallels. The hurried burial of the stone figures and jumbled human remains signals a violent end to this particular elite lineage or house, and perhaps an end to Etowah as a place of regional power as well (King 2004:155).

\section{The Routinization of Hopewell and Mississippian}

One of the points that we want to emphasize is the value of making comparisons between taxonomic categories like Hopewell and Mississippian, comparisons that archaeologists currently undertake too infrequently. It is not far wide of the mark to suggest that comparisons of this kind are typically regarded as ones between apples and oranges. Fruit, yes, but little else to be gained by the comparison. This judgment ignores the valuable insights that can be gained by examining the similarities that often reoccur among unrelated, or but distantly related, historical and cultural contexts, particularly under radically different subsistence economies. The similarities examined herein possess a common connection through the province of religious ritual, which has the great potential of running across the grain of economic and subsistence regime.

Our case studies, Hopewell's Mound 25 and Etowah's Mound C, share many similarities, and while some are superficial, others suggest more significant connections. At the most general level, both are places where people enacted their respective religious ideologies through funerary rites. In each case, moreover, certain of these rites and enactments - the heaping of earth to make mounds, the removal of supernaturally charged objects from circulation, the patterned placement of human burials - were rooted in precedent, if not actually repetitive, and indeed were performed in similar ways by contemporaneous peoples at different sites, such that we may say that each of these cases meets Weber's criteria for routinization. If we look back to Whitehouse's distinction between doctrinal and imagistic modes of religiosity, however, we can be a bit more specific and suggest that the rites performed at Mound 25 and Mound C probably belong somewhere between these poles, between the purely rote (routinized) and the purely ecstatic (charismatic). But as we articulate below, we have reasons to believe that our Hopewell and Mississippian cases occupied different points along this dichotomous axis. Turning our attention to the interregional scale of Hopewell and Mississippian as cultural horizons, we can also say that in each case changes to the dominant subsistence regime precipitated transformations of religious tradition and cosmological knowledge, creating a fertile ground for novel religious movements to take hold across the broad expanse of the precolonial Eastern Woodlands.

Despite these similarities, we have also introduced the concept of routinization to help us explain differences between Hopewell and Mississippian. Thus, while routinization is present to varying degrees in each case, we find the contrasts as interesting and essential for our aims as the similarities. To begin with, in the matter of representation, both humans and animals are common subjects of imagemaking. Take, for example, the various instances of human depiction. In Hopewell we find outlines alone, heads alone, and heads and other body parts in complex visual interplay with nonhuman elements. The representation on the famous engraved human femur from Mound 25 is emblematic. The human here is depicted in ways that reference the animal: antlers, beaks, and other animal parts are woven into the tableau, such that the complexity of the image is capable of eliciting very different responses, depending both on its orientation relative to an observer and on whether we emphasize hatched or blank spaces. These images also materialize the commonplace hallucination of an aura that floats just above the head (Lewis-Williams 2002).

Carr and Case (2005:193-196) describe such changeling aspects in the engraved stone tablets of the Adena culture, a religious manifestation that immediately precedes the Hopewell in the Ohio Valley and neighboring areas. They argue that the intricate designs engraved upon these Adena tablets allude to human-animal transformations during induced trances. The assemblage of tobacco pipes from Mound 25 and other Hopewell sites like Tremper extends this culture of transformation by adding technical and pharmacological means of producing an out-of-body experience. The conspicuous placement of such pipes at Hopewell sites illustrates the importance of smoking as a pathway for connecting with animal spirits and other sacred forces in Hopewell society. Most were deposited in mortuary contexts, whether directly associated with the remains of the dead or not. Their form reveals an important aspect of their role: they were designed to be smoked through a short arm of the pipe that placed the user in close proximity to the bowl. The intimacy of this bowl placement was enhanced when the bowl was shaped into an animal effigy. More often than not, the head of the effigy was carved so as to face the smoker 
full-on, an effect that must have granted the user a spiritual connection to the animal. This effect, too, was heightened by the use in some effigies of eyes of inlayed pearls that were probably intensely animated by the firelight. Together, such elements of Hopewell mortuary ritual underscore its shamanic associations.

In representational art from the Etowah site, humans are depicted not through the lens of shamanic trance but as supernaturals with iconographically important detail (Knight et al. 2001). For example, one of the most significant images on Hightower style engraved shell gorgets from Etowah is that of the winged and raptor-taloned Morning Star (i.e., Birdman) grasping a butterfly or moth (Knight and Franke 2007). An elaborate symbolic code is represented in these and other details that speak to the role of routinization within Mississippian religious art. Specifically, we may recognize that the figure depicted in these Hightower gorgets is the same as that depicted on the Rogan plates-though in a different guise or a different sequence of narrative eventsbecause enough of its particular, essential details (those that connote its essence) are faithfully transposed from one medium to the next. That is, in much of Hopewell representational art, and particularly with respect to humans in art, we see not depictions of specific supernatural figures or events that are recognizable because of their routinized details, but unique, stylized, and highly personalized representations of an act regularly performed in religious events - the spiritual transformation of a human to its animal familiar in a state of induced trance. The Birdman genre of Mississippian art thus transcends the individual ecstatic or transformative experience - and thus is more doctrinal in effect - by memorializing a specific mythohistorical event: Morning Star's apotheosis.

The same may be said for the human statuary genre of Mississippian art as represented by the famous stone figures from Etowah; that is, the forms and attributes of these figures are highly standardized throughout the Mississippian Southeast. For example, male figures are consistently shown either sitting with legs crossed - as in the Etowah figure - or kneeling with one knee drawn up toward the chin. Females are modeled on both knees with their legs tucked underneath. This standardized - and therefore routinized - approach to human representation is much less typical of Hopewell art, which seems again to place its emphasis on individualized experience. Indeed, the human statuary genre, as with the Birdman genre, is not concerned with action and experience in the here-and-now, but rather with linking people in the here-and-now with a primordial past and with situating here-and-now obligations and prerogatives in relation to that past. We suggest that this was the ultimate aim of human representations in Mississippian religious art.
This contrast is also manifested in the way that cosmologically charged objects and sacra were removed from circulation in Hopewell and Mississippian ritual. In both cases, these acts of removal took place during mortuary rites, but here similarities end. The exaggerated character of many Hopewell graves highlights both their ad hoc construction and the superabundant quantity of "grave goods." In fact, this label "grave goods" is itself in question, since in many contexts the bodies of the dead may be thought of as offerings along with material goods. This is particularly the case with cremated remains that were reduced to ashes before their final deposition. Many of the Mound 25 objects themselves were accorded similar treatment of firereduction. Many of the dozens of large obsidian points in Mound 25, for example, were shattered and even melted by the extreme heat. Likewise, the remarkable pipe deposits recovered at Mound City were deliberately fragmented by fire. These deposits may thus be recognized as unique, highly individualized acts, with little standardization across sites or even within the same mound group. Although the mode of these object's removal is often similar (e.g., fire-reduction in an altar), the deposits themselves are typically quite distinct and display little intersite or intrasite routinization.

At Etowah's Mound C, we find that a more predictable array of objects was interred with the dead. Marine shell bead necklaces and headdress elements were supplemented with wristlets and anklets. An axe often accompanied individuals in death, and in special cases sacred bundles are indicated by the tightly wrapped copper "headdress" plates, carved stone palettes, and mineral pigments (King 2004). In other words, whereas an idiosyncratic distribution of objects is found in Hopewell mortuary contexts, a more predictable distribution of preciosities is encountered at Mississippian Etowah. The distribution of such objects within Mound C is sufficiently patterned for King to link different constituencies with different quadrants of the mound, depending on the type of shell gorget deposited with burials. At Hopewell, however, objects were not consistently placed on or near the remains of the dead (Byers 2004). Rather, the actual mortuary context was a continuous and unbounded surface, while at Etowah the dead were placed in purpose-built pits of varying dimensions, from individual to group size. We should also note that the deposition of Mississippian stone statuary, as evidenced by Mound $\mathrm{C}$, is also very predictable. Typically these stone figures received mortuary rites similar to those accorded human dead, and many were placed in their own specially prepared burial pits-like the described male and female figures - or even in stone box graves (e.g., Moorehead 1932:fig. 69a).

Why, then, was ritual performance at Etowah routinized to such a greater degree, or more doctrinal in its emphasis, 
than at the Hopewell site? Here we would like to revisit our suggestion that while Hopewell religion invoked an individual ecstatic experience, Mississippian religion, at least as materialized in places like Etowah's Mound C, situated different kin-based constituencies relative to a primordial past of founding ancestors and culture heroes. Hopewell religion focused on the here-and-now, Mississippian on the there-and-then. This contrast, we believe, may help to explain why Hopewell and Mississippian exhibit such distinctions in routinized ritual practice. It is probably no surprise that an emphasis on the temporal present should result in a less routinized mode of religiosity, one closer to the imagistic than the doctrinal. It is less obvious, though, why the corollary should be so-that an emphasis on the primordial past should result in greater levels of routinization. The concept of tradition might hold the key. A routinized religion is essentially tradition-bound: traditions are beliefs and practices passed down from the time of those founding ancestors and culture heroes to the here-and-now, bearing the imprimatur of the sacred. They are simply so, and any deviations from the sanctioned - indeed routinized - steps of their performance pose an immediate threat to the cosmological order. We may thus think of tradition and religious routine as means of maintaining and safeguarding that order.

Of course, such routines and traditions do more than safeguard a temporally or spiritually distant cosmological order of otherworld denizens. They also reinforce social order among those denizens of the here-and-now. The more successfully routinized a religious movement, the more formally integrated its rites and practices become with those of other social structures. In turn, as the social order ranks its living denizens relative to one another, it derives legitimacy as a faithful reproduction of the primordial in the here-and-now, a literal microcosm. Social inequality is thus understood as a mirror of the cosmos. The more routinized the religion and entangled it becomes with other social structures, the greater the potential disparities between haves and have nots, and the more readily these may persist across generations.

All of which brings us back to the topics of surplus and political economy. Mississippian farmers produced dependable, storable surpluses of maize, a staple cereal crop. As we suggested at the beginning of the chapter, some groups of farmers will always be better situated than others with respect to the resources needed to produce such surpluses, particularly land and labor. Such constituencies can thereby consistently and predictably out-produce their less fortunate neighbors from one season to the next, and eventually from one generation to another. Surpluses - whether produced or procured - finance routinization, so that if certain constituencies are dependably able to produce more than others, they will enjoy a greater ability to shape and direct the nature of the movement. This is Wolf's structural power: the power to set the agenda.

Mississippian rites and traditions, particularly those that governed mortuary practice, thus legitimized and reinforced disparities between kin-based constituencies, whether social houses or lineages. Routinized practices enacted and reenacted the charters that bound constituencies both to one another and to the past: to tradition, to ancestors, to triumphs of culture heroes. Those that were better able to finance the movement's routinization were better able to direct its agenda and to legitimize their political and ritual prerogatives. In Hopewell, the opportunities to create these intergenerational disparities did not exist, and Hopewell religious routine emphasized the highly personal ecstatic experience, likely achieved through membership in sodalities or secret societies that cross-cut kinship ties. The routinization of Hopewell religion clearly prefigures much of the Mississippian repertoire, but it should also be clear that this historical precedence is not the same as the general precedence of evolutionary types. That is, the Hopewell movement was more than an evolutionary stepping stone on the way to Mississippian - the tribal society that paved the path for the latter's chiefdoms. Instead, each worked with similar ideas and practices, but in different historical and economic contexts. The routinization concept offers a framework for focusing less on their relative complexity and more on their respective contexts and histories.

\section{References}

Adams, William R.

1949 Archaeological Notes on Posey County, Indiana. Indianapolis: Indiana Historical Bureau.

Atwater, Caleb

1820 Descriptions of the Antiquities Discovered in the State of Ohio and Other Western States. In Archaeologia Americana: Transactions of the American Antiquarian Society, vol. I. Pp. 105-267. Boston: William Manning.

Beck, Lane A.

1995 Regional Cults and Ethnic Boundaries in "Southern Hopewell." In Regional Approaches to Mortuary Analysis. Lane A. Beck, ed. Pp. 167-187. New York: Plenum.

Beck, Robin A., Jr., Douglas J. Bolender, James A. Brown, and Timothy K. Earle 
2007 Eventful Archaeology: The Place of Space in Structural Transformation. Current Anthropology 48(6):833-860.

\section{Braun, David}

1986 Midwestern Hopewellian Exchange and Supralocal Interaction. In Peer Polity Interaction and Socio-Political Change. Colin Renfrew and John F. Cherry, eds. Pp. 117-126. Cambridge: Cambridge University Press.

Brown, James A.

1976 The Southern Cult Reconsidered. Midcontinental Journal of Archaeology 1:115-135.

1981 The Search for Rank in Prehistoric Burials. In The Archaeology of Death. Robert Chapman, Ian Kinnes, and Klaves Randsborg. Pp. 25-37. Cambridge: Cambridge University Press.

2001 Human Figures and the Southeastern Ancestor Shrine. In Fleeting Identities: Perishable Material Culture in Archaeological Research. Penelope B. Drooker, ed. Pp. 76-93. Occasional Paper, 28. Carbondale: Center for Archaeological Investigations, Southern Illinois University.

2006 Where's the Power in Mound Building? An Eastern Woodlands Perspective. In Leadership and Polity in Mississippian Society. Brian M. Butler and Paul D. Welch, eds. Pp. 197-213. Occasional Paper, 33. Carbondale: Center for Archaeological Investigations, Southern Illinois University.

2007a On the Identity of the Birdman within Mississippian Period Art and Iconography. In Ancient Objects and Sacred Realms: Interpretations of Mississippian Iconography. F. Kent Reilly III and James F. Garber, eds. Pp. 56-106. Austin: University of Texas Press.

2007b The Social House in Southeastern Archaeology. In The Durable House: House Society Models in Archaeology. Robin A. Beck Jr., ed. Pp. 227247. Occasional Paper, 35. Carbondale: Center for Archaeological Investigations, Southern Illinois University.

Brown, James A., and David H. Dye

2007 Severed Heads and Sacred Scalplocks: Mississippian Iconographic Trophies. In The Taking and Displaying of Human Body Parts as Trophies by Americans. Richard J. Chacon and David H. Dye, eds. Pp. 274-294. New York: Kluwer Academic/Plenum.
Buikstra, Jane E.

1976 Hopewell in the Lower Illinois Valley: A Regional Study of Human Biological Variability and Prehistoric Mortuary Behavior. Scientific Papers, 2. Evanston, IL: Northwestern University Archaeological Program.

Byers, A. Martin

2004 The Ohio Hopewell Episode: Paradigm Lost and Paradigm Gained. Akron, $\mathrm{OH}$ : University of Akron Press.

Caldwell, Joseph R.

1964 Interaction Spheres in Prehistory. In Hopewellian Studies. Joseph R. Caldwell and Robert L. Hall, eds. Pp. 133-143. Springfield: Illinois State Museum Scientific Papers.

Carr, Christopher

2005a Historical Insights into the Directions and Limitations of Recent Research on Hopewell. In Gathering Hopewell: Society, Ritual, and Ritual Interaction. Christopher Carr and D. Troy Case, eds. Pp. 51-70. New York: Kluwer Academic/Plenum.

2005b Rethinking Interregional Hopewellian Interaction. In Gathering Hopewell: Society, Ritual, and Ritual Interaction. Christopher Carr and D. Troy Case, eds. Pp. 575-623. New York: Kluwer Academic/Plenum.

Carr, Christopher, and D. Troy Case

2005 The Nature of Leadership in Ohio Hopewellian Societies: Role Segregation and the Transformation from Shamanism. In Gathering Hopewell: Society, Ritual, and Ritual Interaction. Christopher Carr and D. Troy Case, eds. Pp. 177-237. New York: Kluwer Academic/Plenum.

Carr, Christopher, and D. Troy Case, eds.

2005 Gathering Hopewell: Society, Ritual, and Ritual Interaction. New York: Kluwer Academic/ Plenum.

Charles, Douglas, and Jane E. Buikstra, eds.

2006 Recreating Hopewell. Gainesville: University Press of Florida.

Dancey, William S., and Paul J. Pacheco, eds.

1997 Ohio Hopewell Community Organization. Kent, OH: Kent State University Press. 
DeBoer, Warren R.

2004 Little Bighorn on the Scioto: The Rocky Mountain Connection to Ohio Hopewell. American Antiquity 69(1):85-107.

Deuel, Thorne

1952 The Hopewellian Community. In Hopewellian Communities in Illinois. Thorne Deuel, ed. Pp. 249-265. Springfield: Illinois State Museum Scientific Papers.

Eliade, Mircea

1959 The Sacred and the Profane: The Nature of Religion. New York: Harcourt, Brace and World.

Emerson, Thomas E.

1997 Cahokia and the Archaeology of Power. Tuscaloosa: University of Alabama Press.

Emerson, Thomas E., Dale L. McElrath, and Andrew C. Fortier

2000 Late Woodland Societies: Tradition and Transformation across the Midcontinent. Lincoln: University of Nebraska Press.

Ford, James A., and Gordon R. Willey

1940 Crooks Site: A Marksville Period Burial Mound in La Salle Parish, Louisiana. Anthropological Study, 3. New Orleans: Louisiana Geological Survey.

Fritz, Gayle J.

1990 Multiple Pathways to Farming in Precontact Eastern North America. Journal of World Prehistory 4(4):387-435.

Greber, N'omi B., and Katharine C. Ruhl

2000 The Hopewell Site: A Contemporary Analysis Based on the Work of Charles C. Willoughby. 3rd printing. Eastern National.

Gremillion, Kristen J.

2002 Foraging Theory and Hypothesis Testing in Archaeology: An Exploration of Methodological Problems and Solutions. Journal of Anthropological Archaeology 21:142-164.

Griffin, James B.

1967 Eastern North American Archaeology: A Summary. Science 156:175-191.

1985 Changing Concepts of the Prehistoric Mississippian Cultures of the Eastern United States.
In Alabama and the Borderlands: From Prehistory to Statehood. R. Reid Badger and Lawrence A. Clayton, eds. Pp. 40-63. Tuscaloosa: University of Alabama Press.

Griffin, James B., A. A. Gordus, and G. A. Wright

1969 Identification of the Sources of Hopewell Obsidian in the Middle West. American Antiquity 34(1):1-14.

Jones, Lindsey

2000 The Hermeneutics of Sacred Architecture: Experience, Interpretation, Comparison, vol. 1: Monumental Occasions: Reflections on the Eventfulness of Religious Architecture. Cambridge, MA: Harvard Center for the Study of World Religions.

Kelly, John E.

1990a The Emergence of Mississippian Culture in the American Bottom Region. In The Mississippian Emergence. Bruce D. Smith, ed. Pp. 113-152. Washington, DC: Smithsonian Institution Press.

1990b Range Site Community Patterns and the Mississippian Emergence. In The Mississippian Emergence. Bruce D. Smith, ed. Pp. 67-112. Washington, DC: Smithsonian Institution Press.

Kidder, Tristram R.

2002 Woodland Period Archaeology of the Lower Mississippi Valley. In The Woodland Southeast. David G. Anderson and Robert C. Mainfort Jr., eds. Pp. 66-90. Tuscaloosa: University of Alabama Press.

King, Adam

2003 Etowah: The Political History of a Chiefdom Capital. Tuscaloosa: University of Alabama Press.

2004 Power and the Sacred: Mound C and the Etowah Chiefdom. In Hero, Hawk, and Open Hand: American Indian Art of the Ancient Midwest and South. Richard F. Townsend and Robert V. Sharp, eds. Pp. 151-165. New Haven, CT: The Art Institute of Chicago.

Knight, Vernon J., Jr.

1986 The Institutional Organization of Mississippian Religion. American Antiquity 51:675-687.

1990 Social Organization and the Evolution of Hierarchy in Southeastern Chiefdoms. Journal of Anthropological Research 46:1-23. 
Knight, Vernon J., Jr., James A. Brown, and George E. Lankford

2001 On the Subject Matter of Southeastern Ceremonial Complex Art. Southeastern Archaeology 20(2):129-141.

Knight, Vernon J., Jr., and Judith A. Franke

2007 Identification of a Moth/Butterfly Supernatural in Mississippian Art. In Ancient Objects and Sacred Realms: Interpretations of Mississippian Iconography. F. Kent Reilly III and James F. Garber, eds. Pp. 136-151. Austin: University of Texas Press.

Knight, Vernon J., Jr., and Vincas P. Steponaitis, eds.

1998 Archaeology of the Moundville Chiefdom. Washington, DC: Smithsonian Institution Press.

Larson, Lewis H., Jr.

2004 The Submound and Mound Architecture and Features of Mound C, Etowah, Bartow County, Georgia. Southeastern Archaeology 23(2):127141.

\section{Lévi-Strauss, Claude}

1982 The Ways of the Masks. Seattle: University of Washington Press.

Lewis-Williams, David

2002 The Mind in the Cave: Consciousness and the Origins of Art. London: Thames and Hudson.

Meltzer, David

1998 Ephraim Squier, Edwin Davis, and the Making of an American Archaeological Classic. In Ancient Monuments of the Mississippi Valley, 150th Anniversary Edition. E. G. Squier and Edwin H. Davis. Pp. 1-97. Washington, DC: Smithsonian Institution Press.

Mills, William C.

1922 Exploration of the Mound City Group. Ohio Archaeological and Historical Quarterly 31:423584.

Milner, George R.

1998 The Cahokia Chiefdom. Washington, DC: Smithsonian Institution Press.

Moorehead, Warren K.

1922 The Hopewell Mound Group of Ohio. Publi- cation 211, Anthropological Series, vol. VI, no. 5. Chicago: Field Museum of Natural History.

1932 Exploration of the Etowah Site in Georgia. New Haven, CT: Phillips Academy.

Muller, Jon

1997 Mississippian Political Economy. New York: Plenum.

Oyuela-Caycedo, Augusto

2001 The Rise of Religious Routinization: The Study of Changes from Shaman to Priestly Elite. In Mortuary Practices and Ritual Associations: Shamanic Elements in Prehistoric Funerary Context in South America. John E. Staller and Elizabeth J. Currie, eds. Pp. 1-18. BAR International Series, 982. Oxford: British Archaeological Reports.

Pacheco, Paul J., ed.

1996 A View from the Core: A Synthesis of Ohio Hopewell Archaeology. Cincinnati: Ohio Archaeological Council.

Parsons, Talcott

1993 Introduction. In The Sociology of Religion. Max Weber. Pp. xxix-1xxvii. Boston: Beacon.

Pauketat, Timothy R.

1994 The Ascent of Chiefs. Tuscaloosa: University of Alabama Press.

2004 Ancient Cahokia and the Mississippians. Cambridge: Cambridge University Press.

Pauketat, Timothy R., and Thomas E. Emerson, eds.

1997 Cahokia: Domination and Ideology in the Mississippian World. Lincoln: University of Nebraska Press.

Prufer, Olaf H.

1964 The Hopewell Complex of Ohio. In Hopewellian Studies. Joseph R. Caldwell and Robert L. Hall, eds. Pp. 35-84. Springfield: Illinois State Museum Scientific Papers.

1968 Ohio Hopewell Ceramics: An Analysis of the Extant Collections. Anthropological Papers, 63. Museum of Anthropology. Ann Arbor: University of Michigan.

Ruby, Bret J.

1993 An Archaeological Investigation of Mann Phase Settlement Patterns in Southwestern 
Indiana. Glenn A. Black Laboratory of Archaeology Reports of Investigations, 93-118. Bloomington: Indiana University.

1997 The Mann Phase: Hopewellian Subsistence and Settlement Adaptations in the Wabash Lowlands of Southwestern Indiana. Ph.D. dissertation, Department of Anthropology, Indiana University.

Service, Elman R.

1971 Primitive Social Organization: An Evolutionary Perspective. New York: Random House.

Sewell, William H., Jr.

2005 The Logics of History: Social Theory and Social Transformation. Chicago: University of Chicago Press.

Shetrone, Henry C.

1926 Exploration of the Hopewell Group of Prehistoric Earthworks. Ohio Archaeological and Historical Quarterly 35:1-227.

Silverberg, Robert

1968 Mound Builders of Ancient America: The Archaeology of a Myth. New York: New York Graphic Society.

Smith, Bruce D.

1978 Variation in Mississippian Settlement Patterns. In Mississippian Settlement Patterns. Bruce D. Smith, ed. Pp. 479-503. New York: Academic.

1989 Origins of Agriculture in Eastern North America. Science 246:1566-1571.

Squier, E. G., and Edwin H. Davis

1848 Ancient Monuments of the Mississippi Valley: Comprising the Results of Extensive Original Surveys and Explorations. Smithsonian Contributions to Knowledge I. Washington, DC: Gales and Seaton.

Struever, Stuart

1964 The Hopewell Interaction Sphere in RiverineWestern Great Lakes Culture History. In Hopewellian Studies. Joseph R. Caldwell and Robert L. Hall, eds. Pp. 86-106. Springfield: Illinois State Museum Scientific Papers.

1965 Middle Woodland Culture History in the Great Lakes Riverine Area. American Antiquity 31(2):211-223.

Stuart, George E.

2004 The Education of an Archaeologist: The 1954 Sea- son at Etowah, Georgia. Southeastern Archaeology 23(2):144-152.

Tainter, Joseph A.

1977 Woodland Social Change in West-Central Illinois. Mid-Continental Journal of Archaeology 2(1):67-98.

Thomas, Cyrus

1894 Report on the Mound Explorations of the Bureau of American Ethnology. In Twelfth Annual Report of the Bureau of American Ethnology, 1890-1891. Pp. 3-730. Washington, DC: Government Printing Office.

Toth, Alan

1979 The Marksville Connection. In Hopewell Archaeology: The Chillicothe Conference. David S. Brose and N'omi Greber, eds. Pp. 188-199. Kent, $\mathrm{OH}$ : Kent State University Press.

1988 Early Marksville Phases in the Lower Mississippi Valley: A Study of Culture Contact Dynamics. Archaeological Report 21. Jackson: Mississippi Department of Archives and History.

Walthall, John A.

1973 Copena: A Tennessee Valley Middle Woodland Culture. Ph.D. dissertation, Department of Anthropology, University of North Carolina, Chapel Hill.

1979 Hopewell and the Southern Heartland. In Hopewell Archaeology: The Chillicothe Conference. David S. Brose and N'omi Greber, eds. Pp. 200-208. Kent, OH: Kent State University Press.

Waring, Antonio J., and Preston Holder

1945 A Prehistoric Ceremonial Complex in the Southeastern United States. American Anthropologist $47: 1-34$.

Weber, Max

1947 The Theory of Social and Economic Organization. New York: Free Press.

1993 The Sociology of Religion. Boston: Beacon.

Welch, Paul D.

1990 Mississippian Emergence in West Central Alabama. In The Mississippian Emergence. Bruce D. Smith, ed. Pp. 197-225. Washington, DC: Smithsonian Institution Press. 
Whitehouse, Harvey

2004 Modes of Religiosity: A Cognitive Theory of Religious Transmission. Walnut Creek, CA: AltaMira.
Wolf, Eric

1999 Envisioning Power: Ideologies of Dominance and Crisis. Berkeley: University of California Press. 